\title{
FLT3 wt Allele
}

National Cancer Institute

\section{Source}

National Cancer Institute. FLT3 wt Allele. NCI Thesaurus. Code C51546.

Human FLT3 wild-type allele is located within $13 q 12$ and is approximately $97 \mathrm{~kb}$ in length. This allele, which encodes receptor-type tyrosine-protein kinase FLT3 protein, is involved in hematopoiesis may function as a growth factor receptor on hematopoietic stem and/or progenitor cells. 